\title{
Computer Simulation and Automated Calculation of Parameters for Process and Receipt of Deformed Semi-Finished Products of New Precious Metals Alloys for Jewelry Chains Production
}

Iuliia D. Ditkovskaia*, Sergey B. Sidelnikov, Nikolay N. Dovjhenko, Olga S. Lebedeva and Kristina A. Bindareva Siberian Federal University 79 Svobodny, Krasnoyarsk, 660041, Russia

The results of computer-aided design of deformed semi-finished products manufacturing technological processes for the jewelry chains from new alloys of precious metals production are presented. Algorithms and automated calculations adequacy confirmed by computer simulation and physical modeling of bar rolling and drawing processes. Using data on the mechanical properties of new gold, palladium and silver alloys, patented by the authors, the energy-power equipment load of the subject to the limitations on permissible rolling forces and torques are calculated.

Keywords: computer simulation, computer-aided design, technological processes, precious metal alloys, jewelry chains, bar rolling, drawing.

Citation: Ditkovskaia I.D., Sidelnikov S.B., Dovjhenko N.N., Lebedeva O.S., Bindareva K.A. Computer simulation and automated calculation of parameters for process and receipt of deformed semi-finished products of new precious metals alloys for jewelry chains production, J. Sib. Fed. Univ. Eng. technol., 2016, 9(5), 632-642. DOI: 10.17516/1999-494X-20169-5-632-642.

(C) Siberian Federal University. All rights reserved

* Corresponding author E-mail address: yulianomennescio@bk.ru 


\title{
Компьютерное моделирование
}

\section{и автоматизированный расчет}

параметров процесса обработки и получения

деформированных полуфабрикатов

для производства ювелирных цепей

\section{из новых сплавов драгоценных металлов}

\author{
Ю.Д. Дитковская, С.Б. Сидельников, \\ Н.Н. Довженко, О.С. Лебедева, К.А. Биндарева \\ Сибирский федеральный университет \\ Россия, 660041, Красноярск, Свободный, 79
}

\begin{abstract}
В статье приведень результаты автоматизированного проектирования технологических проиессов производства длинномерных деформированных полуфабрикатов для изготовления ювелирных иепей из новых сплавов драгоценных металлов. Алгоритмы и адекватность автоматизированных расчетов подтверждены с помощью компьютерного и физического моделирования процессов сортовой прокатки и волочения. С использованием данных по механическим свойствам новых сплавов золота, палладия и серебра, запатентованных авторами, выполнен расчет энергосиловой загрузки оборудования с учетом ограничений по допустимым усилию и моменту прокатки.
\end{abstract}

Ключевые слова: компьютерное моделирование, автоматизированное проектирование, технологический процесс, сплавы драгоценных металлов, ювелирные цепи, сортовая прокатка, волочение.

Currently, the traditional deformed semi-finished products (rods and wire) manufacturing technology for jewelry chains of precious metal alloys production, including continuous casting billet and multistep bar rolling and drawing processes, is used in almost all plants with the same processing parameters [1]. On the one hand, it makes it easier the automate such processes, but on the other hand, the transition to the deformation of new alloys having improved mechanical and operational characteristics and may lead to defect in the processing step or in step of chains binding. In this regard, a complex approach is actual for improve the technology of jewelry chains production, including the development of new alloys based on precious metals, computer simulation and physical modeling of forming its processes and computer-aided technology and tools design.

The first task of new alloys creating is solved together with Krasnoyarsk Facility of NonFerrous Metals named after Gulidov ("Krastsvetmet" JSC) through the development of new chemical composition of alloys and their structure and properties study [2, 3]. Based on these studies jewelry alloys of gold, palladium and silver were suggested and patented [4-10]. Features of these alloys processing behavior described in the papers [11-15].

As an example, Fig. 1 shows the microstructure of a 925 standard silver alloy [10] studied on polished cast (Fig. 1a) and deformed (Fig. 1b) samples with a microscope Axio Observer D1m (Carl Zeiss, Germany). Metallographic studies of the samples obtained by processing with $98 \%$ deformation, showed that in structure of the new alloy signs of destruction and discontinuities were not observed.

$$
-633-
$$


Mechanical testing of deformed semi-finished products were carried out on the electromechanical universal testing machine «LFM-400» (Walter + Bai AG, Switzerland) and on the universal tensile testing machine «H5K-S» (Hounsfield teste equipment ltd, UK). Research showed that unlike the processing by conventional technology, the current level of this alloy properties [2] allows to eliminate the preliminary and intermediate annealing between the stages of bar rolling without the risk of cracks and breaks.

Next stage of work was the computer simulation of bar rolling and drawing processes, which was conducted with the help of the DEFORM 3D package. In the simulation cold deformation of elastoplastic medium by incompressible tool was considered at $20^{\circ} \mathrm{C}$. For bar rolling (60000 items) rolls rotation frequency in accordance with the technical specifications of the equipment used in manufacturing was $33.3 \mathrm{rev} / \mathrm{min}$, and the rate of friction was assumed equal to 0,12 . In drawing (20,000 items) gripper was moving with speed of $1 \mathrm{~m} / \mathrm{s}$, and the friction rate was equal to 0,08 . The rheological characteristics of the material accepted based on the results of mechanical properties studies of new alloy 925 standard silver semi-finished products. Received models (Fig. 2) allowed to estimate the feasibility of bar rolling and drawing on the proposed routes, metal forming during processing and power parameters.

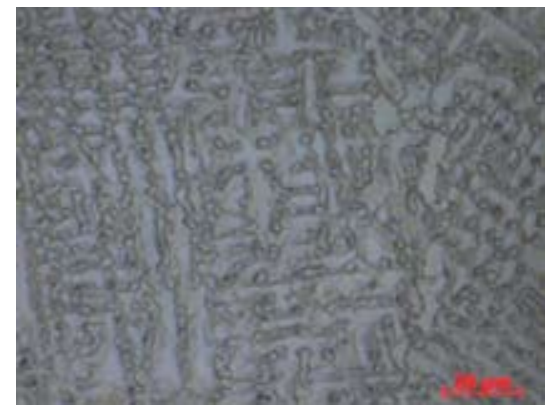

a

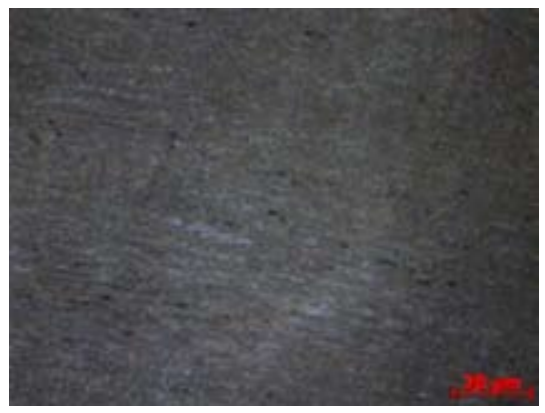

b

Fig. 1. The microstructure of new 925 standard silver alloy in cast (a) and in deformed (b) condition; $\times 1000$

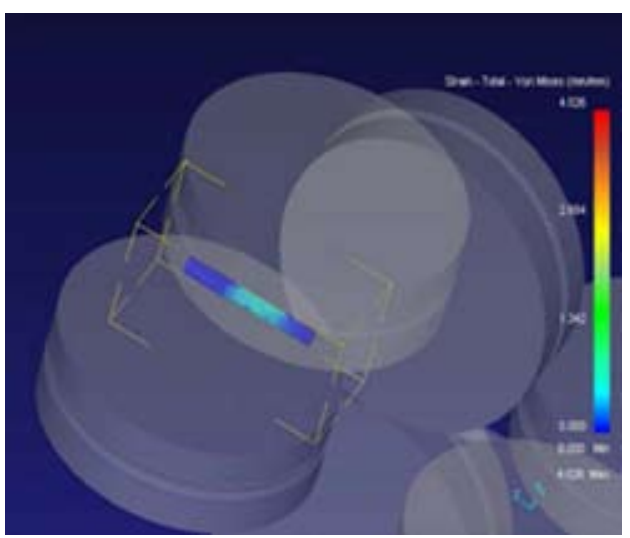

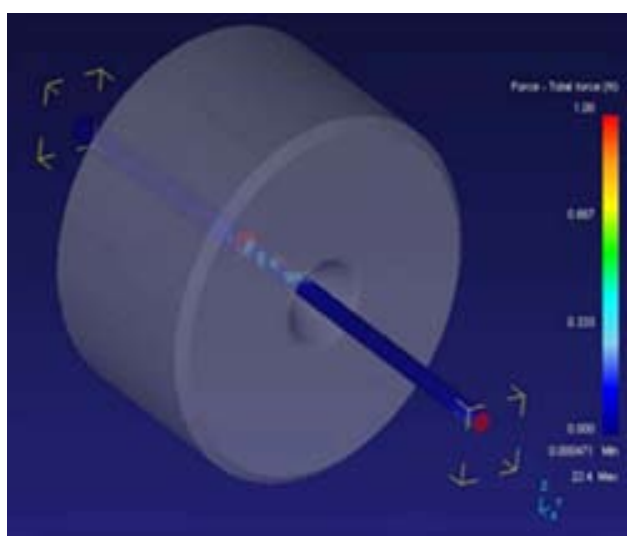

b

Fig. 2. Models of bar rolling (a) and drawing (b) in the DEFORM 3D package 
Analysis of the simulation results showed that the required shape and dimensions of the cross section of $0,25 \mathrm{~mm}$ wire are achieved in 16 bar rolling and 10 drawing passes. Forming of metal till the set parameters going without destroying, the values of the rolling and drawing force reduced gradually during the process.

Using the results of computer modeling in FeatureCAM system the working drawings of bar rolls created, their processing simulated and control programs code generated for roll tool manufacturing on CNC mills (Fig. 3).

The third phase in acting of research was the calculation of rolling and drawing technological modes with the help of "PROVOL" computer-aided design system [11].

Calculation was carried out for available at «Krastsvetmet» JSC equipment and in accordance with applicable in manufacturing technological scheme:

rolling of continuously cast billet with a diameter of $8 \mathrm{~mm}$ in three stages with intermediate annealing till receiving of bar close to the square cross-section with a side of $1 \mathrm{~mm}$ on continuous mills of Famor and BILER types;

drawing of rods till wire with a diameter of $0,25 \mathrm{~mm}$ on COMEVI bull-block wire-drawing machine.

The calculated modes took into account the increased alloys mechanical properties, their hardening during processing, as well as limitations on the power parameters caused by the characteristics of used equipment.

Fig. 4 shows the diagram of force variation during rolling process with the given unit reduction in comparison with the existing bar rolling route at the plant for obtaining of deformed semi-finished products of new 925 standard silver-based alloy.

The calculated rolling modes significantly reduce the number of passes, provide more evenly distribution of passages reduction, thereby creating favorable conditions for metal processing and minimize the potential defects of finished products. The ductility of the alloy allows to eliminate intermediate annealing operations between rolling stages, while force does not exceed permissible $(50,3 \mathrm{kN})$.

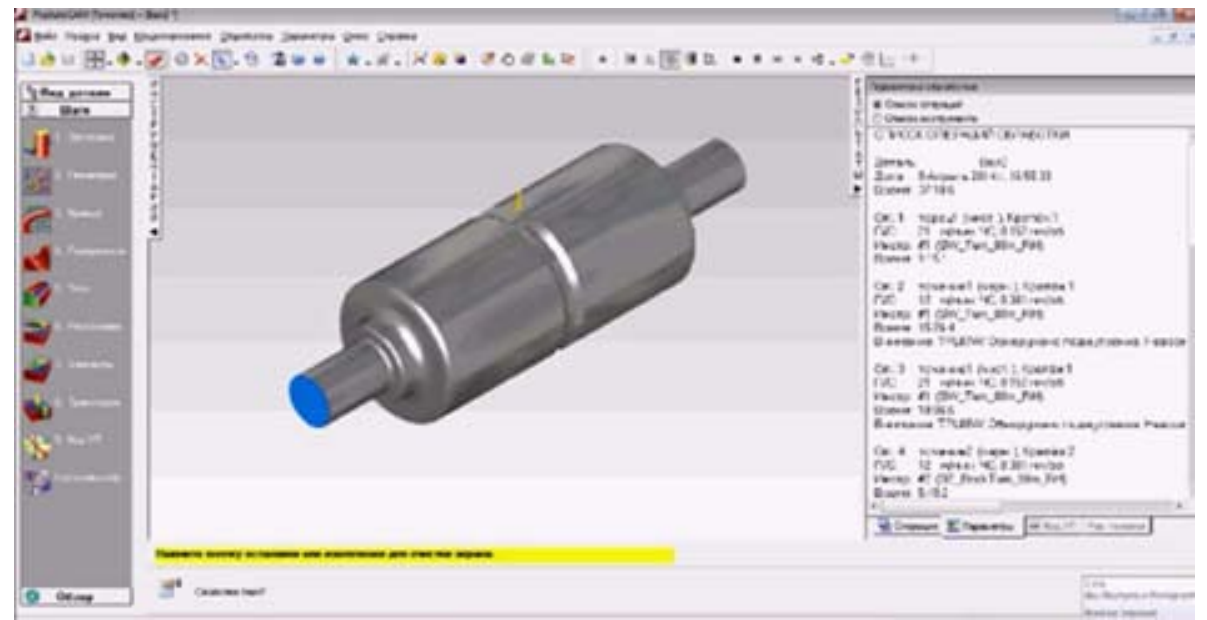

Fig. 3. Simulation of bar rolls and their processing in FeatureCAM system 


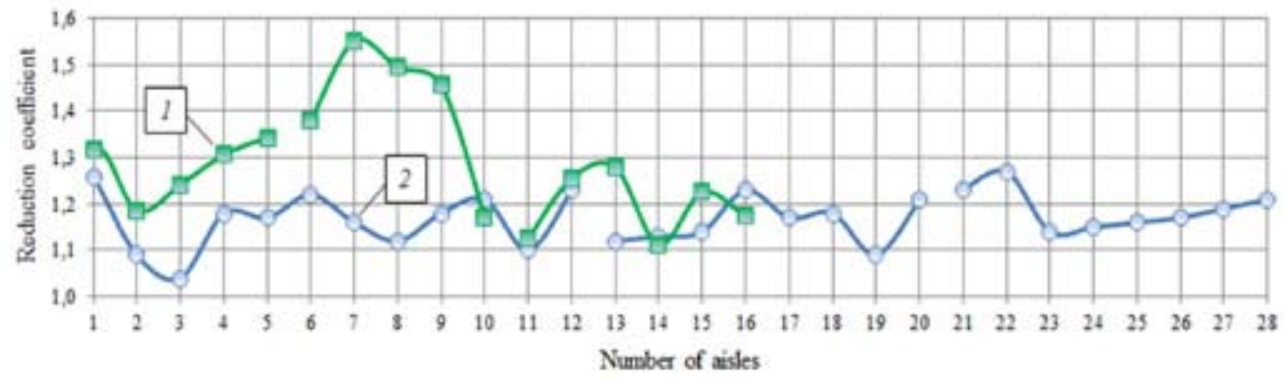

a

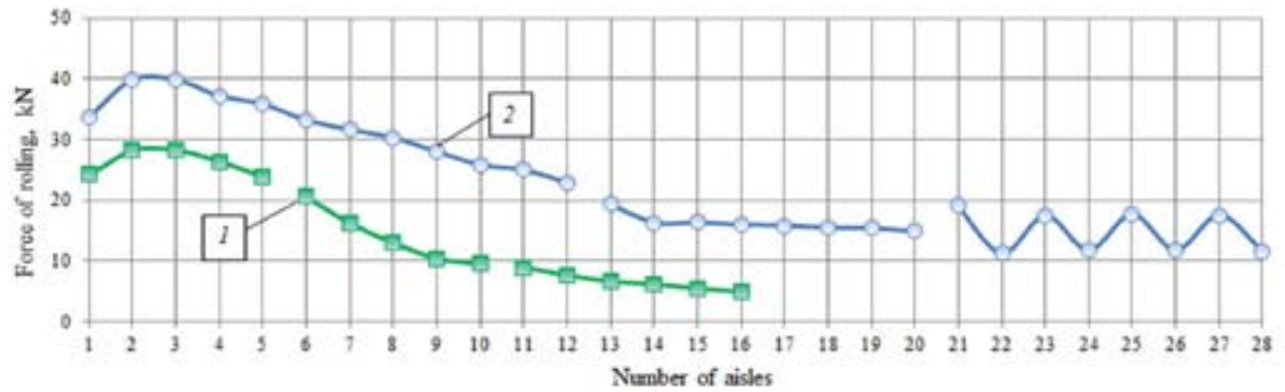

$\mathrm{b}$

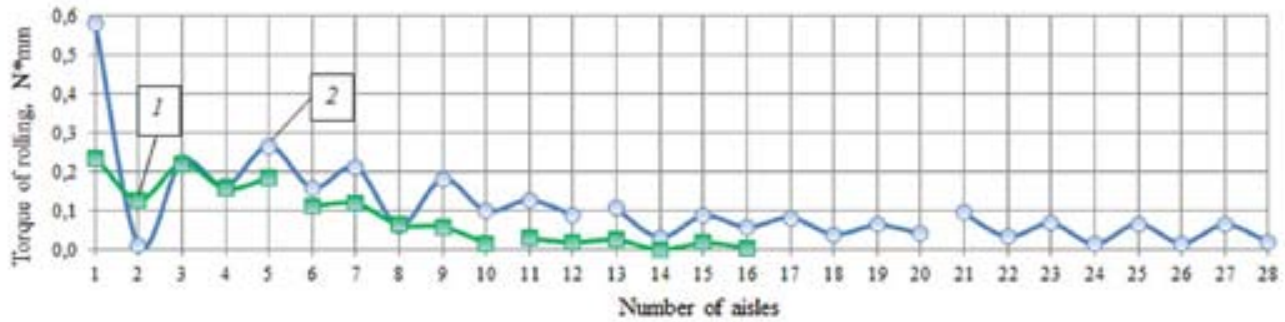

Fig. 4. Changing of unit reduction (a), force (b) and torque (c) of rolling the aisles for the proposed (1) and existing (2) processing of new 925 standard silver alloy routes

Based on developed route in the "PROVOL" program rolls calibration was designed and the working drawings of all calibers the aisles were produced (Fig. 5).

Analysis of the drawing modes (Fig. 6) showed that, unlike used, there is a more evenly reduction change the passages, as well as reducing their value as metal hardening.

The calculated drawing mode is presented in Table 1, its analysis showed that the values of the safety factor changing without peaks and increasing gradually to the last pass.

To verify the adequacy of developed models experimental studies in laboratory conditions were carried out. The cast billet with a diameter of $8 \mathrm{~mm}$ was subjected to bar rolling by the proposed route on the AMBIFILO VELOCE ROSEN $180+200 \times ø 130$ mill of Mario Di Maio company till receiving of bar close to the square cross-section with a side of $1 \mathrm{~mm}$. Wire drawing to a $0,25 \mathrm{~mm}$ diameter was carried out on 10 NFS TRONIC bull-block wire-drawing machine. 


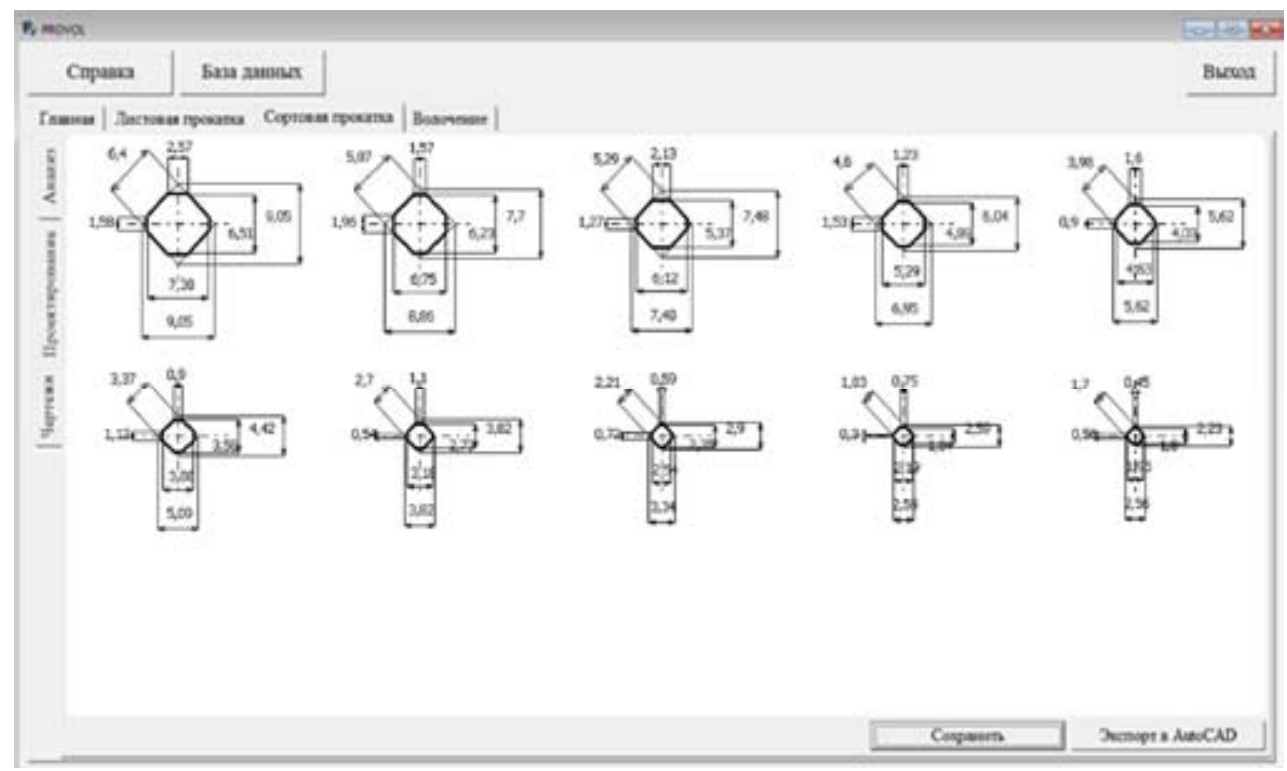

a

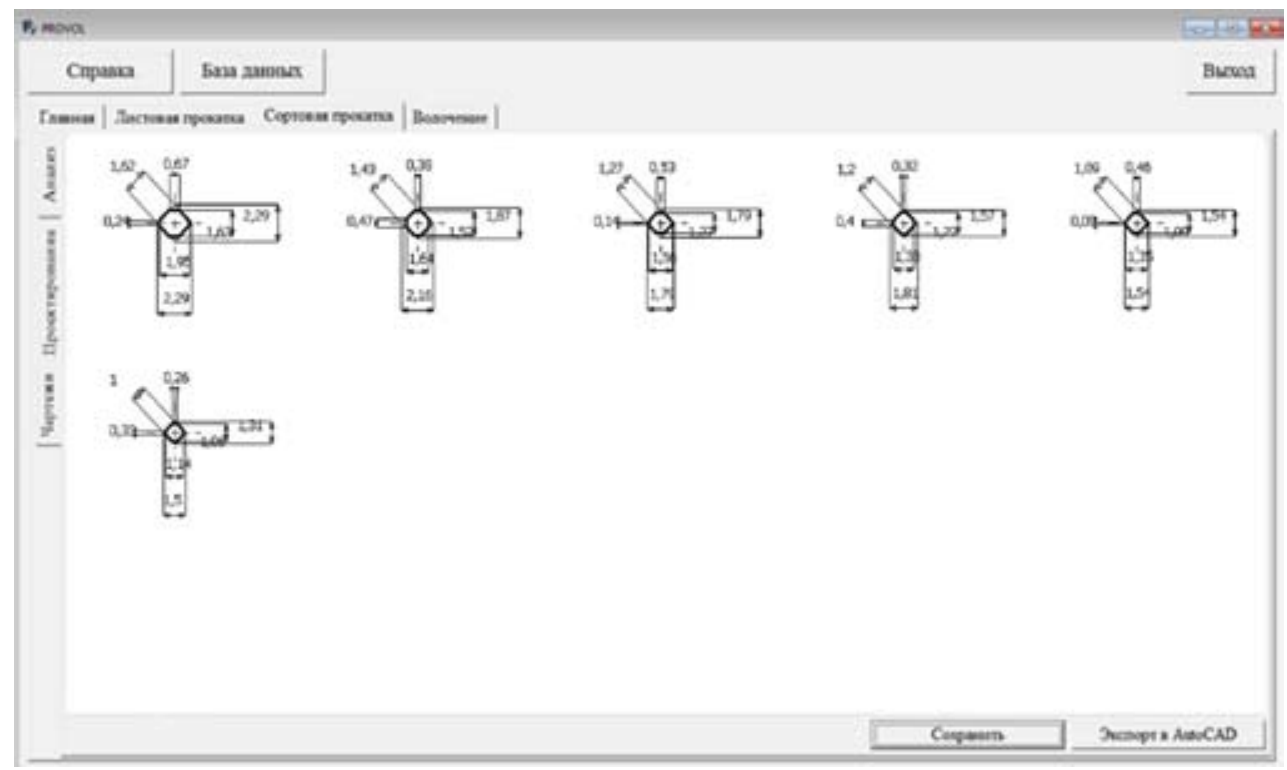

b

Fig. 5. The program «PROVOL» windows for the rolling tool calibration design

From the obtained semi-finished products (Fig. 7) samples for mechanical testing and metallography studies were collected. Alloy ductility allowed to carry out bar rolling and wire drawing without intermediate annealing. Forming of metal on the proposed route passed without the formation of cracks in the bars and wire breaks. For bar rolling billet of $4 \times 4 \mathrm{~mm}$ side size used to obtain bars with $1 \times 1 \mathrm{~mm}$ dimensions.

During the physical modeling of deformed semi-finished products for jeweler chains obtaining process with strain-gauge indicators and strain-gauge station ZET 017-T8 changing 


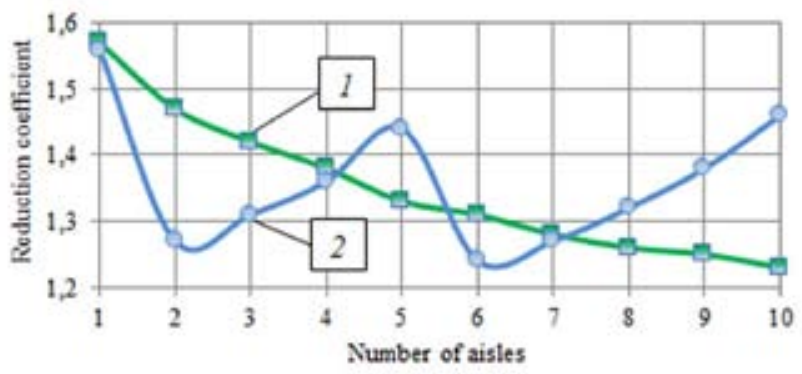

a

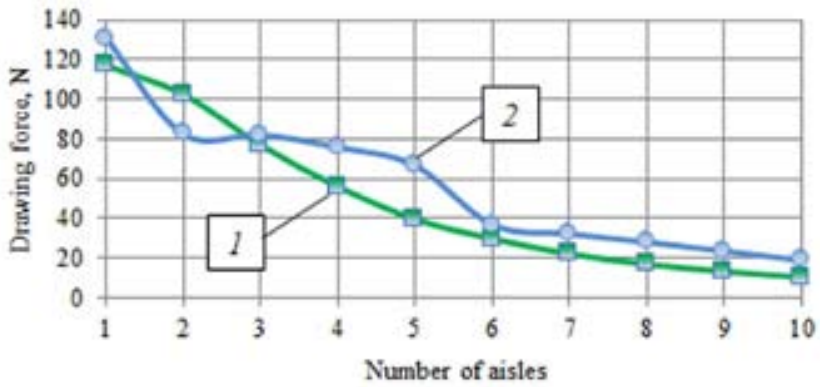

b

Fig. 6. Changing of unit reduction (a) and force of drawing (b) the aisles for the proposed (1) and existing (2) processing routes for new 925 standard silver alloy

Table 1. Developed mode of new 925 standard silver alloy drawing

\begin{tabular}{|c|c|c|c|c|c|c|}
\hline $\begin{array}{c}\text { Number } \\
\text { of aisles }\end{array}$ & Diameter, mm & Unit reduction & $\begin{array}{c}\text { The total } \\
\text { deformation } \\
\text { degree, } \%\end{array}$ & $\begin{array}{c}\text { Drawing } \\
\text { stress, MPa }\end{array}$ & Safety factor & $\begin{array}{c}\text { Drawing } \\
\text { force, N }\end{array}$ \\
\hline 1 & 0,89 & 1,57 & 36,3 & 186,7 & 1,60 & 117,1 \\
\hline 2 & 0,74 & 1,47 & 56,7 & 240,2 & 1,50 & 102,5 \\
\hline 3 & 0,62 & 1,42 & 69,5 & 256,2 & 1,55 & 77,0 \\
\hline 4 & 0,53 & 1,38 & 77,9 & 256,8 & 1,63 & 55,9 \\
\hline 5 & 0,46 & 1,33 & 83,4 & 242,2 & 1,78 & 39,7 \\
\hline 6 & 0,40 & 1,31 & 87,3 & 238,2 & 1,85 & 29,8 \\
\hline 7 & 0,35 & 1,28 & 90,0 & 226,0 & 1,98 & 22,1 \\
\hline 8 & 0,31 & 1,26 & 92,1 & 217,7 & 2,08 & 16,9 \\
\hline 9 & 0,28 & 1,25 & 93,7 & 214,0 & 2,13 & 13,3 \\
\hline 10 & 0,25 & 1,23 & 94,9 & 204,0 & 2,25 & 10,3 \\
\hline
\end{tabular}

of the force of bar rolling the aisles was registered. Compare the values of forces obtained by calculation and experimentally demonstrated that calculation error does not exceed an average of $5-7 \%$ (Fig. 8).

Thus, with the help of the developed software rational modes of deformed semi-finished products processing were designed for the manufacture of jewelry chains from new alloys based on precious metals. The analysis showed that in comparison with existing they allow to reduce amount of 


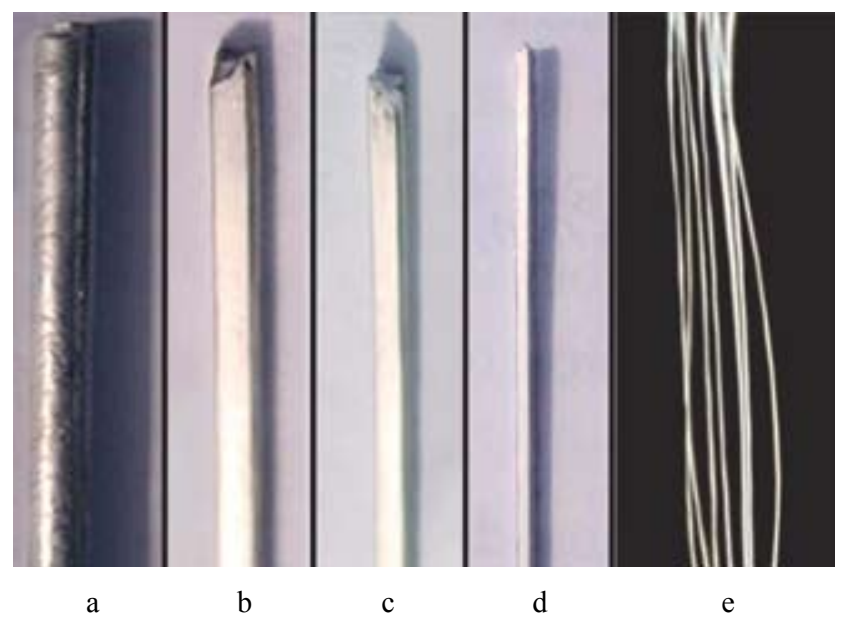

Fig. 7. Cast blank (a), bars $(b-d)$ and wire (e) from the new 925 standard silver alloy

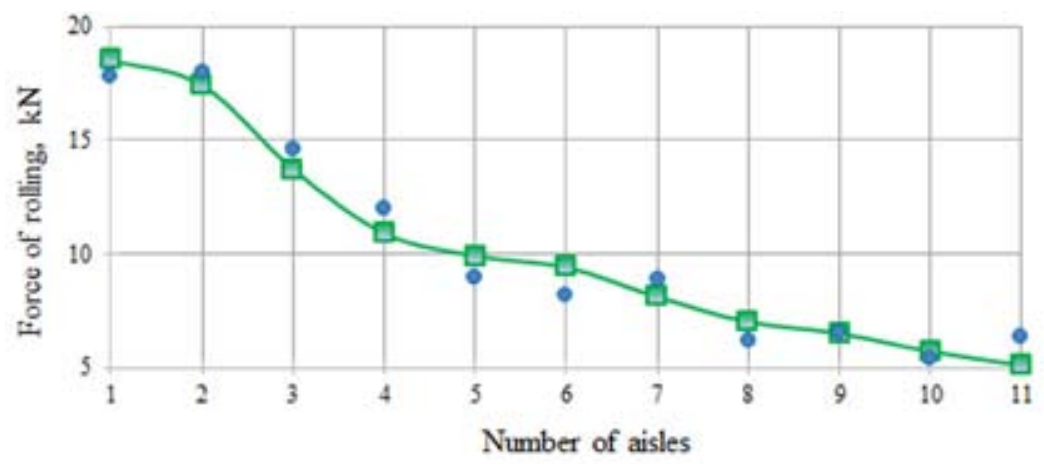

Fig. 8. Changing the experimental (1) and calculated (2) rolling force the aisles

technological processes, energy-power load of equipment and the probability of occurrence finished product defects.

The feasibility of bar rolling and drawing processes on the proposed routes has been confirmed by simulation in a specialized software system using the method of finite element analysis. Designed modes were tested during physical modeling. Results of experimental studies allow to recommend them to introduction in the jewelry chains manufacture at "Krastsvetmet" JSC.

Used complex of software tools and developed computer models of bar rolling and drawing can be recommend for analysis of existing technologies and creation of processing modes for new alloys based on gold, palladium and silver.

\section{References}

[1] Сидельников С.Б., Дитковская Ю.Д., Лебедева О.С., Лопатина Е.С., Рудницкий Э.А., Леонтьева Е.С. Анализ и проектирование технологии получения проволоки ювелирного назначения из новых сплавов драгоценных металлов. Вестник Южно-Уральского государственного университета. Металлургия, 2015, 15 (4), 108 - 115. [Sidel'nikov S.B., 
Ditkovskaya Yu.D., Lebedeva O.S., Lopatina E.S., Rudnitskiy E.A., Leont'eva E.S. Analysis and Technology Design for the Production of Jewelry Wire from New Precious Metal Alloys. Bulletin of the South Ural State University. Metallurgy, 2015, 15 (4), 108 - 115 (in Russian)].

[2] Сидельников С.Б., Довженко, Н.Н., Дитковская Ю.Д., Лопатина Е.С., Лебедева О.С., Рудницкий Э.А. Создание новый сплавов ювелирного назначения из многокомпонентных систем драгоценных металлов и технологий их обработки. Вестник Магнитогорского государственного технического университета им. Г.И. Носова, 2015, 4, 38 - 44 [Sidelnikov S.B., Dovzhenko N.N., Ditkovskaya Yu.D., Lopatina E.S., Lebedeva O.S., Rudnitsky E.A. Creation of new jewelry alloys from multicomponent precious-metal systems and their processing technologies. Vestnik Magnitogorskogo Gosudarstvennogo Tekhnicheskogo Universiteta im. G.I. Nosov [Vestnik of Nosov Magnitogorsk State Technical University]. 2015, 4, 38 - 44 (in Russian)].

[3] Сидельников С.Б., Беляев С.В., Лебедева О.С., Павлов Е.А., Столяров А.В., Усков И.В., Феськов Е.В., Гайлис Ю.Д. Разработка и исследование технологии получения деформированных полуфабрикатов из сплавов золота 585-й пробы. Цветные металлы - 2012, 2012. 802 - 807 [Sidelnikov S.B., Belyaev S.V., Lebedeva O.S., Pavlov E.A., Stolyarov A.V., Uskov I.V., Feskov E.V., Gaylis Y.D. Development and research of technology for 585-th probe gold alloys deformed semifinished products manufacturing. Non-ferrous metals - 2012, 2012. 802 - 807 (in Russian)].

[4] Сплав на основе золота белого цвета 585 пробы: пат. 2430982 Рос. Федерация: МПК С22C5/02 / Сидельников С.Б., Мальцев Э.В., Довженко Н.Н., Шульгин Д.Р., Биронт В.С., Столяров А.В., Шубаков А.П., Усков И.В., Беляев С.В., Лопатина Е.С., Лебедева О.С., Бабушкин О.В.; Патентообладатели: ОАО «Красноярский завод цветных металлов имени В.Н. Гулидова» (ОАО «Красцветмет») и ФГАОУ ВПО «Сибирский федеральный университет». - №2010121640/02; заявл. 27.05.2010; опубл. 10.10.2011, Бюл. № 28 [An 585 probe white gold alloy: Pat. 2430982 Russian Federation: IPC C22C5/02 / Sidelnikov S.B., Maltsev E.V., Dovzhenko N.N., Shulgin D.R., Biront V.S., Stolyarov A.V., Shubakov A.P., Uskov I.V., Belyaev S.V., Lopatina E.S., Lebedeva O.S., Babushkin O.V.; The patent holders: JSC "Krasnoyarsk Nonferrous Metals Plant named after V.N. Gulidov" (JSC “Krastsvetmet”) and FSAEI HPE “Siberian Federal University”. - №2010121640/02; appl. 27.05.2010; publ. 10.10.2011, Bull. №28 (in Russian)].

[5] Сплав на основе золота белого цвета 585 пробы: пат. 2439179 Рос. Федерация: МПК С22С5/02 / Сидельников С.Б., Мальцев Э.В., Довженко Н.Н., Шульгин Д.Р., Столяров А.В., Шубаков А.П., Лопатина Е.С., Бабушкин О.В.; Патентообладатель: ОАО «Красноярский завод цветных металлов имени В.Н. Гулидова» (ОАО «Красцветмет). - №2011101102/02; заявл. 12.01.2011; опубл. 10.01.2011, Бюл. № 1 [An 585 probe white gold alloy: Pat. 2439179 Russian Federation: IPC C22C5/02 / Sidelnikov S.B., Maltsev E.V., Dovzhenko N.N., Shulgin D.R., Stolyarov A.V., Shubakov A.P., Lopatina E.S., Babushkin O.V.; The patent holder: JSC "Krasnoyarsk Nonferrous Metals Plant named after V.N. Gulidov” (JSC “Krastsvetmet”). - №2011101102/02; appl. 12.01.2011; publ. 10.01.2011, Bull. №1 (in Russian)].

[6] Сплав на основе золота: пат. 2391425 Рос. Федерация: МПК С22С5/02 / Сидельников С.Б., Довженко Н.Н., Биронт В.С., Столяров А.В., Усков И.В., Лопатина Е.С., Лебедева О.С., Шульгин Д.Р., Шубаков А.П., Бабушкин О.В.; Патентообладатели: ОАО «Красноярский завод цветных металлов имени В.Н. Гулидова» (ОАО «Красцветмет») и ФГАОУ ВПО «Сибирский федеральный университет». - № 2009105722/02; заявл. 18.02.2009; опубл. 10.06.2010, Бюл. № 16 
[An gold based alloy: Pat. 2391425 Russian Federation: IPC C22C5/02 / Sidelnikov S.B., Dovzhenko N.N., Biront V.S., Stolyarov A.V., Uskov I.V., Lopatina E.S., Lebedeva O.S., Shulgin D.R., Shubakov A.P., Babushkin O.V.; The patent holders: JSC «Krasnoyarsk Nonferrous Metals Plant named after V.N. Gulidov» (JSC «Krastsvetmet») and FSAEI HPE «Siberian Federal University». - № 2009105722/02; appl. 18.02.2009; publ. 10.06.2010, Bull. №16 (in Russian)].

[7] Сплав красного цвета на основе золота 585 пробы: пат. 2514898 Рос. Федерация: МПК С22С5/02 / Довженко Н.Н., Сидельников С.Б., Лопатина Е.С., Столяров А.В., Беляев С.В., Усков И.В., Лебедева О.С., Гайлис Ю.Д.; Патентообладатель: ФГАОУ ВПО «Сибирский федеральный университет». - №2013116285/02; заявл. 09.04.2013; опубл. 10.05.2014, Бюл. № 13 [An 585 probe red gold alloy: Pat. 2514898 Russian Federation: IPC C22C5/02 / Dovzhenko N.N., Sidelnikov S.B., Lopatina E.S., Stolyarov A.V., Belyaev S.V., Uskov I.V., Lebedeva O.S., Gaylis Y.D.; The patent holder: FSAEI HPE “Siberian Federal University”. - №2013116285/02; appl. 09.04.2013; publ. 10.05.2014, Bull. №13 (in Russian)].

[8] Сплав на основе палладия: пат. 2392339 Рос. Федерация: МПК С22C5/04 / Сидельников С.Б., Довженко Н.Н., Биронт В.С., Шубаков А.П., Столяров А.В., Рудницкий Э.А., Усков И.В., Бабушкин О.В., Лопатина Е.С., Глухов В.Н.; Патентообладатель: ФГАОУ ВПО «Сибирский федеральный университет». - №2008150687/02; заявл. 22.12.2008; опубл. 20.06.2010, Бюл. № 17 [An palladium based alloy: Pat. 2392339 Russian Federation: IPC C22C5/04 / Sidelnikov S.B., Dovzhenko N.N., Biront V.S., Shubakov A.P., Stolyarov A.V., Rudnitskiy E.A., Uskov I.V., Babushkin O.V., Lopatina E.S., Glukhov V.N.; The patent holder: FSAEI HPE “Siberian Federal University”. - №2008150687/02; appl. 22.12.2008; publ. 20.06.2010, Bull. №17 (in Russian)].

[9] Сплав на основе палладия 850 пробы: пат. 2574936 Рос. Федерация: МПК С22C5/04 / Довженко Н.Н., Сидельников С.Б., Беляев С.В., Усков И.В., Столяров А.В., Рудницкий Э.А., Лопатина Е.С., Дитковская Ю.Д., Усков Д.И.; Патентообладатель: ФГАОУ ВПО «Сибирский федеральный университет». - №2014130807/02; заявл. 24.07.2014; опубл. 10.02.2016. Бюл. №4 [An palladium 850 probe alloy: Pat. 2574936 Russian Federation: IPC C22C5/04 / Dovzhenko N.N., Sidelnikov S.B., Belyaev S.V., Uskov I.V., Stolyarov A.V., Rudnitskiy E.A., Lopatina E.S., Ditkovskaia I.D., Uskov D.I.; The patent holder: FSAEI HPE “Siberian Federal University”. - №2014130807/02; appl. 24.07.2014; publ. 10.02.2016, Bull. №4 (in Russian)].

[10] Сплав белого цвета на основе серебра 925 пробы, модифицированный кремнием: пат. 2513502 Рос. Федерация: МПК С22С5/08 / Сидельников С.Б., Беляев С.В., Столяров А.В., Усков И.В., Аникина В.И., Усков Д.И., Аникин А.И., Богданов Д.В., Гайлис Ю.Д., Феськов Е.В.; Патентообладатель: ФГАОУ ВПО «Сибирский федеральный университет». - № 2013117667/02; заявл. 16.04.2013; опубл. 20.04.2013, Бюл. № 11 [An 925 probe white silver alloy, modified by silicon: Pat. 2513502 Russian Federation: IPC C22C5/08 / Sidelnikov S.B., Belyaev S.V., Stolyarov A.V., Uskov I.V., Anikina V.I., Uskov D.I., Anikin A.I., Bogdanov D.V., Gaylis Y.D., Feskov E.V.; The patent holder: FSAEI HPE “Siberian Federal University”. - № 2013117667/02; appl. 16.04.2013; publ. 20.04.2013, Bull. №11 (in Russian)].

[11] Фачченда В. Справочник по финишной обработке в производстве ювелирных изделий из золота, Омск: Дедал-Пресс, 2007, 68 с. [Faccenda. V. Handbook on Finishing in Gold Jewellery Manufacture, Omsk: Dedal-Press, 2007, 68 p. (in Russian)].

$$
-641-
$$


[12] Christopher W. Corti. Basic Metallurgy of the Precious Metals, Part I. The Santa Fe Symposium on Jewelry Manufacturing Technology 2011, 2011, 145 - 182.

[13] Christopher W. Corti. Basic Metallurgy of the Precious Metals, Part II: Development of Alloy Microstructure through Solidification and Working. The Santa Fe Symposium on Jewelry Manufacturing Technology 2012, 2012, 123 - 144.

[14] Christopher W. Corti. Basic Metallurgy of the Precious Metals, Part IV: Deformation Processing, Joining and Corrosion. The Santa Fe Symposium on Jewelry Manufacturing Technology 2014, 2014, $111-137$.

[15] Бреполь, Э. Теория и практика ювелирного дела. СПб.: Соло, 2000. 528 с. [Brepol, Е. Theory and Practice of jewelry. Sankt-Petersburg: Solo, 2000. 528 p. (in Russian)].

[16] «PROVOL»: свидетельство о государственной регистрации программы для ЭВМ № 2015612273 / Сидельников С.Б., Беляев С.В., Лебедева О.С., Рудницкий Э.А., Дитковская Ю.Д., Леонтьева Е.С., Соляникова А.С.; Правообладатель: ФГАОУ ВПО «Сибирский федеральный университет». - № 2014663306; заявл. 19.12.2014; опубл. 20.03.2015 [«PROVOL»: the computer program state registration certificate № 2015612273 / Sidelnikov S.B., Belyaev S.V., Lebedeva O.S., Rudnitskiy E.A., Ditkovskaia I.D., Leont'eva E.S. Solyanikova A.S.; Copyright: FGAOU VPO «Siberian Federal University.» - № 2014663306; appl. 19/12/2014; publ. 03/20/2015 (in Russian)]. 